\title{
NATURAL LIBERTY AND TRANSFERENCE OF SOVEREIGNTY IN WILLIAM OF OCKHAM
}

\author{
Libertad natural y transferencia de soberanía en Guillermo de Ockham \\ Manuel Méndez Alonzo \\ Universidade Catolica Rio Grande do Sul / Ljubljana
}

\begin{abstract}
The objective of this works in to analyze the conditions of transference of sovereignty and the concept of natural liberty in William of Ockham. Firstly, I briefly explain some antecedents of the conflict of 'investidures'. Secondly, I will show that Ockham advanced the existence of a set of natural rights hold by the community. This permitted to argue against the Papal interference in the secular sphere, but also to set limits to the emperor himself and grant the individual with natural rights. Thirdly, I explain the differences between ius fori and ius poli and I suggest that Ockham did not provide point of contact between these laws, excepting in the case of liberty. Finally, I revise briefly Ockham's term translation imperii.
\end{abstract}

Key words: Community, Natural Liberty, Natural Rights, Divine Law, Translatio Imperii.

\section{RESUMEN}

El objetivo de este trabajo es analizar las condiciones de transferencia de soberanía y el concepto de libertad natural en Guillermo de Ockham. En primer lugar, pretendo explicar algunos de los antecedentes del conflicto de las investiduras. En segundo lugar, trataré de demostrar que Ockham propone la existencia de un grupo de derechos naturales detentados por la comunidad. Esto le permitió criticar la interferencia papal en la esfera secular, pero también poner límites a la autoridad imperial y otorgar derechos básicos a los individuos. En tercer lugar, haré la diferencia entre ius fori y ius poli; sostengo que Ockham no provee puntos claros de contactos entre ambas legislaciones exceptuando el caso de la libertad. Finalmente me interesa explicar de forma breve cómo se entiende el término translatio imperii.

Palabras Clave: Comunidad, Libertad natural, Derechos Naturales, Ley Divina, Translatio Imperii.

\section{INTRODUCTION}

Political theories in medieval Europe during the fourteenth century were determined by the confluence of two factors. The first was political. The crisis between the Papacy and the Holy Roman Empire followed the demands of sovereignty of European states against any claim of universality. ${ }^{1}$ The second element was the reception of Aristotle's philosophy. In the early Middle Ages, medieval political theory was a conceptual system configured by the confluence of elements inherited from ancient Greek and Roman political philosophy. With the rediscovery of Aristotle's Politics, medieval political philosophy distanced itself from ancient philosophy and began to display elements closer to modernity. ${ }^{2}$

1 De Lagarde, George, La naissance de l'esprit lä̈que au déclin du moyen Âge, vol 4, Louvain, E. Nauwelaerts, 1962, p9.

2 Bertelloni, Francisco, «La teoría política medieval entre la tradición clásica y la modernidad», El pensamiento político en la Edad Media, Pedro Roche Arnas (ed.), Madrid, Editorial Centro de Estudios Ramón Areces, 2009, p17. 
One of the major philosophers during this transition was William of Ockham. He supported the cause of Ludwig of Bayern against John XXII. Ockham's political works were militant. He dealt with the problem of poverty, the relation of church and state, and the notion of property rights. He also became involved in the most important dispute of his time: the investiture controversy. According to Chevalier, Ockham's political works reflected his nominalism and individualism. ${ }^{3}$ The confluence of these features resulted in a complex political system which mistrusted all concentrations of power. ${ }^{4}$

First, I will present a historical review which highlights (a) the development of medieval communal life and (b) the reception of Aristotle's political works and their influence, then explaining briefly (c) the notion of community during the late Middle Ages. Second, I will explore Ockham's notions of natural right and liberty. Third, I will explain the differences between ius fori and ius poli. Finally, I will mention the conditions by which political authority was transferred and obtained its legitimacy.

\section{POLITICAL NATURE, COMMUNITY AND THE RECOVERY OF ARISTOTLE'S POLITICAL HOUGHT}

The political thought of the late Middle Ages was greatly determined by the conflict between the Papacy and the Holy Roman Empire. For De Lagarde, the fourteenth century crisis of medieval institutions was caused by two events. The first was the election of Ludwig of Bavaria after the battle of Mühldorf in 1322. Ludwig's challenges to papal authority in 1323 were followed by his excommunication and mutual accusations of heresy. ${ }^{5}$ The second event was John XXII's condemnation of Franciscan theses of poverty. This led prominent members of the Franciscan order to align themselves with the German emperor.

As Peña Euguren has pointed out, before the crisis of the investitures the orbis christianus was seen as a homogeneous object ${ }^{6}$ in which popes and emperors were portrayed as principles of unity. Both the emperor and the pope were considered fundamental to the harmony of the political body. As Bertelloni points out, medieval philosophers accepted the existence of two powers, one temporal and the other spiritual; both were considered as potestates with different functions. ${ }^{7}$ The reception of Aristotelian philosophy led to a differentiation of these powers and further confrontation, but it also produced the need to justify the ontological status and theoretical foundations of the political order. ${ }^{8}$ Another element resulting from this crisis was the increase in town life in northern Italy. The political literature produced by Italian citystates placed the sovereignty in the community. ${ }^{9}$ Jurists and dictatores turned their attention to Aristotle and Roman law in order to defend their independence and their regimes.

3 Chevalier, François, Histoire de la pensée politique. Paris, Grande Bibliothèque Payot, 1993, p212.

4 Ibid., 212-213.

5 De Lagarde, op.cit., p8.

6 Peña Eguren, Esteban, La filosofía política de Guillermo de Ockham, Madrid, Encuentro, 2005, p20.

7 Bertelloni, op.cit., p23.

8 Ibid., 24.

9 When these communes became de facto independent from the Empire, they began to choose a republican popular government to rule themselves. Although the methods to elect varied from city to city, the ultimate sovereignty lay in the people. It is important to say that the 'people' who were capable of participating in political life were a small minority. Medieval society was divided into grades and, thus, only a minority had a legal status of citizenship and exercised their full political rights. Even so, the level of representation of these cities was very high compare to those of other European kingdoms. Canning, J.P., "Introduction: politics, institutions and ideas", The Cambridge History of Medieval Political Thought, J.H. Burns (ed.), Cambridge, Cambridge U. Press, 2007, pp353-354. 
Due to Aristotle's influence, man was considered a political animal by nature; social life was one of his features. ${ }^{10}$ The world view developed during the early Middle Ages, in which natural law and divine law were identified, began to be abandoned. ${ }^{11}$ Roman civil law provided the most articulate language for understanding the political dimensions of man. The rediscovery of both political traditions produced the anti-juridical mentality of the early Middle Ages and developed into a political theory in which political notions were grounded in natural rights. ${ }^{12}$

Narrowly speaking, the community represented an association of individuals with different functions on the basis of oath with juridical personality. ${ }^{13}$ Based on the ideas of Aristotle, Thomas Aquinas established the goals of the communities: It is a space to live well, and the city was the ultimate expression of this social space. ${ }^{14}$ As a result, medieval scholars attempted to delineate the functions of the secular and the spiritual spheres. The conclusion was that monarchs and religious ministers had differentiated tasks within the Christian community. ${ }^{15}$ The other immediate result produced claims against universality, followed by the emergence of group awareness and the desire to organize the commune (as in the case of the northern Italy communes) without external interference. ${ }^{16}$

The community was comprised of "the whole body of individuals that compose it", ${ }^{17}$ whether this be a group, the civitas, a collegium, or more broadly, all of humanity. This means, following Quillet, that the structure of medieval society was comprised of a network of relations and arrangements whose ultimate goal was to keep peace among the members of the community. ${ }^{18}$ Therefore, the aim of a polity was to safeguard personal needs along with communal obligations.

Since the second half of the thirteenth century, medieval political scholars assigned the origin of political authority within the community. To justify this statement, they turned to concepts of Roman law such as civitas ${ }^{19}$ and communitas. ${ }^{20}$ Aquinas affirmed that communities were natural creations ${ }^{21}$ and were formed by differentiated groups with common customs,

10 Ibid., p360.

11 Ibid.,p361.

12 Villey, Michel. La Formation de la Pensée Juridique Moderne, Paris, PUF, 2003, p250.

13 Quillet, Jeannine, «Community, counsel and representation», The Cambridge History of Medieval Political Thought, pp522-523.

14 Ibid., p528.

15 Canning, op.cit., p362.

16 Ibid., p525.

17 Ibid., p537.

18 Ibid., pp537-538.

19 The term civitas seems to refer to a reality that is not possible to find in the political context of Europe during the thirteenth century. Although it is possible to find civic life in Italy, Flanders and some German cities, it is not possible to use them as models for the kingdoms which ruled Northern Europe. Medieval scholars were aware of the limitations of this term. For this reason, they preferred to use other terms with wider significance, such as communitas politica, communicatio politica, civilis communication, ordination politica, civilis multitudo and the often used civis vel regnum. De Lagarde, op.cit., 1967, $\mathrm{p} 85$.

20 In William of Moerbeke's translation of Aristotle's Politics communitas is a translation of the Greek koinonia, which refers to the civil community constituted by the city. The bonds that create koinonia could be interest and friendship. For thirteenth century scholars, communitas refers to a plurality of individuals who shared a common objective without relations of dominion. Quillet, op.cit., pp526.

21 «Deo summo rege, in quantum per lumen rationis divinitus datum sibi, in suis actibus se ipsum dirigeret. Naturale autem est homini ut sit animal sociale et politicum, in multitudine vivens, magis etiam quam omnia alia animalia, quod quidem naturalis necessitas declarat...Homo autem institutus est nullo horum sibi a natura praeparato, sed loco omnium data est ei ratio, per quam sibi haec omnia officio manuum posset praeparare, ad 
laws, and language. ${ }^{22}$ Aquinas defined the community as an association preserved by laws. The regnum constituted the perfect community. For authors such as John of Paris and Dante, the regnum unified different cities into one political entity which became the perfect community. This was called a civitas aut regnum. ${ }^{23}$

Nonetheless, the religious ideals which forged medieval society were still a fundamental part of life during the fourteenth century. For European scholars of the late Middle Ages, the purpose of human life was still salvation, but the superiority of the spiritual over everyday politics was now out of the question. Salvation determined the private and public behavior of the subject, including that of the prince. Popes and princes were seen as the heads of the political body, and they had to interact to achieve this supernatural end. For Aquinas, religious and secular authorities coincided in their respective jurisdictions and objectives, but his political theory prefigured two separate sovereignties. ${ }^{24}$ Medieval scholarship accepted (even a radical scholar such as Marsilius of Padua) the necessity of priests and the priesthood; the contentious subject was to determine their temporal power. ${ }^{25}$

\section{OCKHAM'S THEORY OF POLITICAL POWER: COMMUNITY AND LIBERTY}

Ockham shared with Marsilius of Padua the belief that the main source of discord was the papal doctrine of plenitude of power, but in general he mistrusted all concentrations of power. ${ }^{26}$ Another important feature in Ockham's political writings is his circumstantialism. When Ockham judged the government of a political association, he was interested mainly, as James Blythe argues, in pragmatic concerns ${ }^{27}$ For the English philosopher, circumstances - as well as time, geographical location and culture-determined the political rule of political associations. Despite these pragmatic concerns, Ockham advanced a definition of good government: a state in which bad people are easily restrained and good people are not disturbed.

For Ockham, God gave men not only a life, but also the means to improve it. However, the role of God was passive since he only provided the means to judge the necessity of government. ${ }^{28}$ God allowed men to have goods and to institute authorities in order to have a political life and to live well. ${ }^{29}$ In the state of innocence, the existence of an authority was not necessary; all men were equal in nature and sin had not yet appeared. When wicked men began to disturb other men, God awarded men the privilege of instituting chiefs to maintain order. ${ }^{30}$ Therefore, men did not establish their chiefs by natural needs or by an exigency of nature, but by rationally recognizing their utility. ${ }^{31}$ When a chief is put into his position by any community, the exercise of his authority is similar to the authority exerted in a property. ${ }^{32}$

quae omnia praeparanda unus homo non sufficit. Nam unus homo per se sufficienter vitam transigere non posset. Est igitur homini naturale quod in societate multorum vivat». Aquinas, Thomas, De regno, «Corpus Thomisticum.

S. Thomae de Aquino Opera Omnia», <http://www.corpusthomisticum.org/iopera.html>, I

22 Quillet,op.cit., pp528.

23 Lagarde, op.cit., 1967, p88.

24 Bertelloni, op.cit., p19.

25 Strauss, Leo. Naturel et Histoire. Francia, Flammarion, 1987, p278.

26 Ibid., 212-213.

27 Blythe, James M, «Civic Humanism' and medieval political thought» Renaissance Civic Humanism: Reappraisals and Reflections. James Hankins (ed.), Cambridge, Cambridge U. Press, 2003, p.69.

28 De Lagarde, op.cit., p.219.

29 Ibid., p.220.

30 Idem.

31 De Lagarde, op.cit., p. 221.

32 Ghisalberti, Alessandro. Introduzione a Ockham. Roma-Bari, Laterza, 1976, p.97. 
For Ockham, the creation of secular authorities guaranteed the common good of individuals. This common good, according to Camastra, was the product of a praxis, oriented to valorize the autonomy of the individual and recognize personal liberty. ${ }^{33}$ In Quillet's opinion, Ockham's effort was oriented to limit the power of secular authorities by assuring the existence of natural political rights (for example, the ruler could not deprive his community of liberty) with an inalienable character. ${ }^{34}$

Natural rights were communia et communis est omnium possessio, et omnium una libertas. ${ }^{35}$ In this way, Ockham advanced a group of natural rights that could not be taken away without a good cause. However, Ockham did not make any effort to distinguish between natural and divine right, but he suggested the existence of inherent natural rights that 'set limits to the God-given power of a supreme pontiff'. ${ }^{36}$ As a result, by safeguarding the civil and natural rights of individuals, Ockham could limit the power of secular and religious authorities. ${ }^{37}$

Ex quibus aliisque quampluribus colligitur quod Christiani per legem evangelicam et instructionem Christi sunt a servitute multiplici liberati, et quod non sunt per legem evangelicam tanta servitute oppressi quanta Iudaei per legem veterem premebantur. ${ }^{38}$

For Ockham, the laws that guaranteed freedom and the common good found their inspiration in evangelical law. ${ }^{39}$ Thus, liberty is secured not only by positive right, but by divine law. ${ }^{40}$ This was granted to mortals by God to protect them against all attempts to enslave Christians by pagan laws or by $\sin .{ }^{41}$ By locating liberty within the sphere of natural law and rational duty, Ockham's assertion gave liberty an inalienable character because it prevents depriving anyone of freedom without good cause. ${ }^{42}$ In giving divine character to liberty, Ockham found an effective mode to secure it. ${ }^{43}$

For Ockham, Christian liberty was understood as spiritual autonomy granted by God and inherent to mankind. Following Tierney's viewpoint, personal liberty must be respected as any other right (as the right to own possessions or the right to occupy office) because it was granted by God and nature. ${ }^{44}$ The libertates related to an area of free moral choice and autonomy in which men could respond to divine demands. As a result, individual liberty, for Ockham, is a subject out of existence..$^{45}$

33 Camastra, Francesco, «Chiesa, Società e Stato: La lezione filosófico-politica di Gugliemo d'Ockham», Il Filosofo e la Politica. William of Ockham, Milano, Rusconi, 1999, p.54.

34 Quillet, op.cit., p.538.

35 Ockham, «Octo questiones», Il Filosofo e la Politica, p.378

36 Tierney, op.cit., p.186.

37 Ibid. p.187.

38 Ockham, William of, «An princeps», La Spada e lo Scettro: Due Scritti Politici, Milano, Biblioteca Universale Rizzoli, 1997, p.52

39 Camastra, op.cit., p.54.

40 «ex enim Christiana ex institutione Christi est lex libertatis, ia quod per ordinationem non est maioris nec tantae servitutis quantae fuit lex vetus». Ockham, «An princeps», pp.48, 50

41 «...lex evangelica non solum dicitur lex libertatis quia liberat Christianos a servitute peccati et legis Mosaique, sed etiam quia Christiani per legem evangelicam nec maiori nec tanta servitude premuntur quanta fuit servitus veteris legis». Ockham, « An princeps», p.54.

42 Dunbabin, Jean. «Government». The Cambridge History of Medieval Political Thought, 350-1450. p.511.

43 «si contra multa minora non currit praescriptio, multo magis non debet currere contra optimum principatum , licet currere debeat pro ipso: sicut non contra libertatem sed pro libertate currit praescriptio; qui enim per decenium in statu steterit libertatis, pro libero est habendus». Ockham, «Octo quaestiones», p.298.

44 Tierney, op.cit., p.189.

45 Black, Anthony. «The Conciliar Movement».The Cambridge History of Medieval Political Tought, p601. 
By spinning an idea of natural rights that could not be taken away without cause, Ockham 'associated the evangelical sphere and ius naturale in a way that set limits to the God-given power of a supreme pontiff'. ${ }^{46}$ As we have seen, evangelical liberty limited papal power by safeguarding the rights of the community against the pope's claims. ${ }^{47}$ The purpose of locating liberty within the sphere of natural law and rational duty was to prevent any abuses of authorities over their subjects. ${ }^{48}$

The emphasis on individual rights was balanced with a concern for the common good of the citizens. ${ }^{49}$ Ockham resorted to the Decretum to assert that laws are instituted for the common utility of the citizens. The aim was to prove that the pope must serve the community and not dominate it. ${ }^{50}$ At the same time, for Ockham it was important to demonstrate that the community preserves its freedom because rulers could not alienate the natural rights of their subjects. ${ }^{51}$

Non enim potest quicunque dominis temporalis habere maius dominium vel potestatem super servum suum quam ut posit omnia praecipere ei, quaecunque non sunt contra legem divinam nec contra ius naturale. Ad illa enim, quae sunt contraria legi divinae et iuri naturalis indispensabili, nulla potestas imperatoris, regis vel cuiuscunque alterius respect cuiuscunque servi se extendit. ${ }^{52}$

Ockham considered that the best regime 'should exist for the sake of the common good, nor for the ruler's own good'. ${ }^{33}$ The best regime for Ockham, according to Peña Eguren, was secular, but it extended to the ecclesiastical sphere. ${ }^{54}$ In the same sense, Blythe considers that Ockham awards the pope special functions to investigate and judge ecclesiastical crimes but as just one of the Roman people..$^{55}$ The raison d'être for this was to preserve peace and justice. Otherwise, instituting different authorities, for example, one secular and another ecclesiastical, would produce strife and confusion.

Ockham's objective was to demonstrate the legitimacy of secular power without resorting to the Scriptures. As a result, Ockham needed to prove that political regimes were not products of a divine transference of power. As will be mentioned in the next section, he placed the source of legitimate political power in the people. ${ }^{56}$ This represented a criticism of the ecclesiastical authorities and Ghibelline jurists. At the same time, this position served to limit effectively the authority of the princes ${ }^{57}$ by advancing a number of obligations, such as the creation of laws and the maintenance of the common good.

46 Tierney, Brian. The Idea of Natural Rights. United States of America: Emory U.Press, 1998, p186.

47 Ibid., p187.

48 Dunbabin, op.cit., p511.

49 Idem.

50 Ibid., p.190.

51 Tierney, op.cit., p183.

52 Ockham, «An princeps», p56.

53 Ockham, William of, «Eight Questions on the Power of the Pope», A Letter to the Friars Minor and Other Writings, (ed.) Arthur Stephen and John Kilkullen, Cambridge, Cambridge U. Press, 1995, p313.

54 Peña Eguren, op.cit., p220.

55 Blythe, op.cit.,p51.

56 «Unico verbo respondetur quia cum dicitur quod potestas imperialis et universaliter omnis potestas licita et legitima est a Deo non tamen a solo Deo. Sed est a Deo per homines et talis est potestas imperialis quae est a Deo sed per homines». Ockham, William of. Dialogus. «William of Ockham: Dialogus. Latin and English translation under the auspices of the Medieval Text Editorial Committee of the British Academy», <http://www. britac.ac.uk/pubs/dialogus/>, III, Track.II, chap. XXVI.

57 Tierney, op.cit., p183 
Hoc testari videtur glossa dist. 17, quae ait, "Habet Romana ecclesia auctoritatem a Deo sed imperator a populo", utcunque legimus. Hinc etiam glossa dist. 2. Lex est constitutio populi ait, "Olim populus constituit leges sed hodie transtulit hanc potestatem in imperatorem." $\mathrm{Ab}$ illo autem est imperium qui imperatori contulit potestatem condendi leges. Ergo a populo est imperium. ${ }^{58}$

\section{IUS FORI, IUS POLI AND THE LAW OF NATURE}

For Ockham, it was necessary to differentiate between the spheres of positive right and the law of nature. Bastit argues, for instances, that Ockham was capable of distinguishing these spheres by marking the differences between ius fori and ius poli. The ius fori was comparable, Bastit continues, to the concept of positive right and is distinguished by its artificial and obligatory character. In opposition, ius poli encompasses the prerogatives known only by revelation. That is, they have an eternal character because they are ordered by God and, thus, an immutable nature. ${ }^{59}$ Ius poli are apprehended by an act of reason. However, it is important to remember that reason for Ockham is not immutable or abstract but an act of will. ${ }^{60}$

The problem was that Ockham did not make any effort to relate the ius fori with ius poli. In other words, it appeared that ius poli had no direct influence on the ius fori ${ }^{61}$ Since they do not have points of contact, in a determinate moment these legislations could contradict each other. For example, the acts forbidden by ius poli did not have a mandatory character and might not be punished by the ius fori.

The situation became more complex since Ockham also recognized the existence of some positive rights (liberty is the best example) which are in conformity with divine right and the law of nature. ${ }^{62}$ In Tierney's opinion, this might be due to the fact that Ockham's concept of law of nature was not grounded on a theological basis, but in Roman legal authors such as Gratian, Alanus and the Decretum. ${ }^{63}$

The natural law for Ockham has three meanings: First, it is a law 'in conformity with natural reason'. Second, it consists of immutable precepts which transcend the area of custom but are liable to be changed by human legislators. Third, though the law of nature was considered by Ockham to be the rational response of men to contingency, this response did not have any juridical value. ${ }^{64}$ For example, the election of governors was a rational response to certain needs, but it could not be considered God's direct mandate. ${ }^{65}$

58 Ockham, Dialogus, III, Track.II, chap. XXVII.

59 Bastit, Michel, La Naissance de la Loi Moderne, Paris, PUF-Leviathan, 1987, p251.

60 Ibid., p252.

61 Bastit considered that for Ockham the lex iniqua does not lose its character as law. Its nature is being separated from the jus poli. In Bastit's opinion, in Ockham's theses are inoculated by the principles of juridical positivism. Ibid., pp.265-266.

62 «L'empereur dispose, en vertu d'un sorte de pacte par lequel les sujets lui ont remis leur pourvoir, de la totalité du pourvoir politique, mais il doit aussi exercer ce pourvoir en conformité avec les règles du droit divin et naturel». Ibid., p266.

63 Tierney, op.cit., p.179.

64 Ibid, p178.

65 As Gierke pointed out, it was highly characteristic of medieval doctrines for the positive law to seem incapable of protecting acquired rights. The inalienability of the rights against the authority could be maintained only if these rights could be sustained on a firmer ground. An institution such as property had its roots in the Ius Gentium and natural law. The contract with the sovereign was also bound by natural law, so it followed that every 
Consequently for Ockham, the law of nature could be interpreted according to the circumstances and the will of the people. ${ }^{66}$

De Lagarde argues that Ockham maintained the sphere of positive law separate from the scope of divine law. For Villey, this means that even the most important of religious precepts, including the Ten Commandments, constituted rational mandates without any juridical value. ${ }^{67}$ The laws that guide men in the natural state were followed by a pre-social state in which humanity was not ruled by any legislation. ${ }^{68}$ Henceforth, the rational character of the law of nature stripped it of its obligatory sense. ${ }^{69}$ Ius poli precepts exist in an implicit way, even if they are not clearly stated. ${ }^{70}$

\section{TRANSLATIO IMPERII AND HOW THE ROMAN EMPIRE WAS ESTABLISHED BY THE ROMAN PEOPLE}

As mentioned before, the purpose of Ockham's political works was to demonstrate that secular authority was not instituted by some divine transference of power. The only legitimate source of political power remaining was the people. ${ }^{71}$ To say it another way: The Roman Empire was created when the Roman people transferred their authority to make laws and organize the community to one person - the emperor.

In Blythe's interpretation, Ockham conceded absolutist powers to the emperor because, after the power was granted, it could not be easily revoked. Furthermore, the emperor had no superiors. ${ }^{72}$ This opinion is rejected by Tierney and Gierke for whom the role of the Roman emperor in Ockham's works was to perform actions necessary for the sake of the community. ${ }^{73}$ He placed boundaries on the emperor's authority; thus, the people became the only person with limitless sovereignty. ${ }^{74}$ To prove this point, Ockham made reference to ancient Roman history. The Roman people, depending on the circumstances, changed their political regime. For example, in one moment in their history, the Romans were ruled by consuls, but in another they were governed by kings. What is important is that all these political regimes were approved by the people..$^{75}$ Moreover, the Romans understood

right sanctioned by the State, but it could not be violate by it. Gierke, Otto, The Political Theories of the Middle Age, tr. Frederich William Maitland, Cambridge, Cambridge U. Press, 1958, pp.80-81.

66 Tierney, op.cit, pp.180, 182.

67 Villey, op.cit., p232.

68 Idem.

69 Ibid., p233.

70 Tierney, op.cit., p182.

71 «Unico verbo respondetur quia cum dicitur quod potestas imperialis et universaliter omnis potestas licita et legitima est a Deo non tamen a solo Deo. Sed est a Deo per homines et talis est potestas imperialis quae est a Deo sed per homines». Ockham, Dialogus, III, Track.II, chap. XXV

72 Blythe, op.cit., p51.

73 Tierney, op.cit., p184.

74 «...it is Ockham who most emphatically teaches that this is not merely a limit set to the power of the Monarch but a limit to the power of the State itself; for according to him, the limitation of imperial rights by rights of the individuals rest upon the fact that the Populus, which transferred its power to the Princeps, had itself no unbounded power». Gierke, op.cit., p179.

75 «De mutatione autem modi dominandi et regendi obedientes habetur in scripturis fide dignis. Aliquando enim habuerunt reges aliquando consules aliquando unum qui mutabatur singulis annis. Ultimo autem imperatorem elegerunt qui absque mutatione omnibus imperaret. Ergo a Romanis fuit Romanum imperium institutum». Ockham, Dialogus, III, Track.II, chap. XXVII. 
that it was necessary for the common good of the world that one emperor dominated all the people. In this way, the Romans conquered the ancient world, but the power of managing and controlling the emperor fell to the Roman people. Those who opposed this decision were seen as hindering the commonwealth. ${ }^{76}$

For Ockham, the Roman emperor was a valid authority because he had been previously approved by Roman citizens. ${ }^{77}$ However, this might not be the case for nations subjugated by the Roman Empire. Ockham solved this problem by admitting that the empire had obtained its legitimacy through a combination of just wars and the voluntary submission of neighboring nations. ${ }^{78}$ Consequently, these nations, who later formed part of the Roman Empire, gave their consent a posteriori. ${ }^{79}$

Respondetur quod si Romani ordinando de imperio ex solo amore boni communis et rei publicae moti fuissent et non ex libidine dominandi aut vanam gloriam non intendissent nec aliquam intentionem corruptam habuissent in hoc absque peccato fuissent et forte aliqui eorum in acquirendo imperium vel consentiendo acquisitioni imperii minime peccaverunt. ${ }^{80}$

Ockham needed to demonstrate that the Roman emperor received his potestas by free men. ${ }^{81}$ As de Lagarde points out, this could be done by extending the authority of the Roman Empire to the emperor's reign. ${ }^{82}$ As result, two conclusions may be derived from Ockham's interpretation of Roman history: a) The Roman emperor should not behave tyrannically because he rules over free men. ${ }^{83}$ b) The people constituted a legitimate source of political power which existed before Christian revelation.

Ockham needed to establish the existence of valid forms of transference of power besides the divine one. Ockham turned to the concept of translatio imperii. This transference of power was made from one nation to another. ${ }^{84}$ The core of the argument is that people had the

76 «Ad hoc dupliciter respondetur: primo quod Romani cernebant quod necessarium fuit pro utilitate communi totius mundi unum imperatorem universis mortalibus dominari. Ideo qui contradixerunt unitati imperii tanquam impedientes boni communis potestas ordinandi de imperio fuerunt». Ockham, Dialogus, III, Track.II, chap. XXVII.

77 «Respondetur quod teste Glossa Extra, De constitutionibus, Cum omnes, quoniam aliqui plures unum sunt collegium quantum ad illa quae ex necessitate facienda sufficit quod a maiori parte fiant». Ockham, Dialogus, III, Track.II, chap. XXVII.

78 Blythe, op.cit., p52.

79 Peña Eguren, op.cit., p273.

80 Ockham, Dialogus, III, Track.II, chap. XXVII.

81 «Uno modo, quod illa translatio non fuit facta a papa, sed a Romanis, quórum ab initio fuit imperium et a quibus imperator primo accepit imperium; qui omnem potestatem suam habuit a populo Romano, qui, quamvis regulariter omnem potestatem suam regularitier regendi propter bonum commune transtulerint in imperatorem, non tamen transtulerunt in ipsum potestatem dominandi seu regendi despotice nec a se abdicaverrunt omnem potestatem casualiter disponendi de imperio». Ockham, «Octo questiones», Il filosofo e la politica, p382.

82 De Lagarde, op.cit., p.127.

83 «Si enim haec fecissent, se fecissent servos imperatoris strictissime accipiendo vocabulum servi et ila nullatenus liberi remansisent; et per consequens imperator non habuisset imperator regalem». Ockham, «Octo questiones», Il filosofo e la politica, p382.

84 «Quod Romanum imperium potest transferri tribus exemplis probatur. Primum exemplum est quod translatum fuit de Romanis in Graecos 69, dist. Constantinus. Secundum exemplum est quod translatum fuit de Graecis in Romanos in personam Caroli magni, Extra, De electione, Venerabilem. Tertium exemplum est quod fuit translatum de Francigenis in Theutonicos. Unde glossa 63. dist. Ego Ludovicus ait super verbo Francorum, 
right to transfer their power from one ruler to another, if that was useful for the commonwealth. ${ }^{85}$ In this way, the Roman people gave the power to Augustus, then, they passed the power to the Byzantines and finally, to Charlemagne. ${ }^{86}$

After the translatio imperii was accepted by the Roman people, the emperor would obey no other person than God. ${ }^{87}$ However, Ockham did not deprive the community of all their political power because they held the right to change the emperor if he failed to safeguard the common good. ${ }^{88}$

Ockham's objective was to demonstrate that: a) The rule of Caesar, before Christianity became the official religion of the Roman Empire, was legitimate; b) the transference of authority was not divine, as Ghibelline jurists sought to affirm, and it existed in the pagan peoples ${ }^{89}$ For Ockham, the authority which the pagans exerted could be considered legal even by God. In other words, if the power of pagan kings was not tyrannical or illegitimate, it was approved by God. ${ }^{0}$ To prove this point, Ockham quoted the Gospels in which the authority of the Caesars is recognized. ${ }^{91}$

Ockham rejected the papal theory of political power because it did not grant true autonomy to civil power. However, Ockham was not ready to grant sovereignty to the people. Ockham accepted that the empire came from the people - a populo est imperium ${ }^{92}$ - but he recognized the sovereignty of the emperor after this process of transference of power from the subjects. ${ }^{93}$ At the same time, Ockham pointed out that the rights of the Roman people were inalienable. By this affirmation, in De Lagarde's opinion, Ockham advanced an idea of popular sovereignty exerted by the community, which could be denied only if the community committed an inexpiable crime. ${ }^{44}$ Finally, for Ockham, the descendents of the Roman people were not deprived of their natural political right, and the authority of pagan kings was legitimated because they had the consent of their communities. ${ }^{95}$

\section{CONCLUSION}

By proposing the existence of natural and inalienable rights, Ockham could set limits on political authority. Ockham's answer was to place the origin of power in the community itself. In this way, he contested the pope's political pretentions and limited the power of the Roman emperor. This discussion of natural rights would be reintroduced in the sixteenth century by the School of Salamanca.

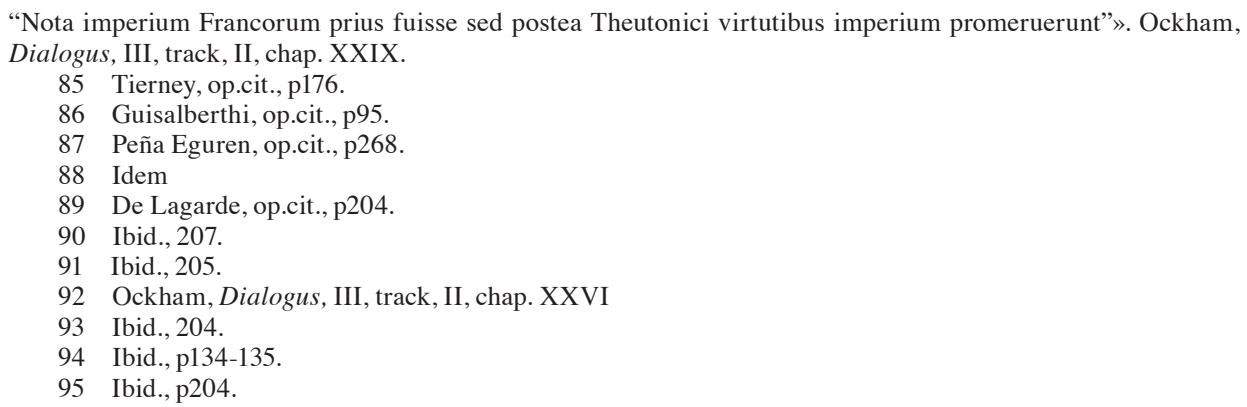


Ockham accepted a limited participation of the ecclesiastical curia in the political affairs of the empire only if this was made by a delegation of the people in a very limited scope.${ }^{96} \mathrm{As}$ a result, Ockham based the legitimacy of the empire in a secular origin.

Recibido: 10 de diciembre de 2012

Manuel Méndez Alonzo

Aceptado: 1 de mayo de 2013

manuel.mendez.alonzo@gmail.com

96 «Respondetur quod nemo potest hic dicere, nisi libere et diligenter vidisset privilegia papae vel registra fide digna vel scripturas autenticas de huiusmodi translatione vel collatione iuris super imperium facta papae, eo quod Romani poterant conferre papae pinguius ius vel minus pingue super imperium. Poterant etiam tale ius dare sedi apostolicae vel solummodo personae papae. Poterant etiam dare papae pro una vice vel pro pluribus». Ockham, Dialogus, op.cit., III, track II, chap.XXX 